changes in the status of the black-headed gull have occurred in the Mersey and other rivers where there was no great public feeding of the gulls, and the flocks became regular winter inhabitants of the park lakes.

\section{Regional Survey Atlas of the Croydon District}

THE ambitious project for a regional survey atlas covering some 200 square miles around the Borough of Croydon was begun by the Croydon Natural History and Scientific Society so long ago as 1913. Despite the difficulties of war-time conditions, it has been continued by the issue this year of a third series of maps and printed matter (Proc. Croydon and Dist. Nat. Hist. and Sci. Soc.). In contrast to similar local surveys which have been attempted in other parts of Great Britain, the Croydon scheme is based essentially on the idea that a regional survey is never of necessity complete, and hence the actual work is to be contained in a loose-leaf binder which was issued with the first series of maps; the contents as originally planned can therefore be added to as experience and the progress of knowledge may dictate.

The two previous issues of maps have included base maps, maps dealing with rainfall, relief, drainage and a number of historical maps as well as some referring to population and planning. The present, or third, issue contains only one map-of bronze age remains-but has the textual statement by Mr. Fagg on geological structure and history, illustrated by geological sections, and an account of the natural vegetation, together with a list of plants normally found on the chalk of the region, a section contributed by Mr. C. T. Prime. The description of the bronze age map is by Mr. A. W. G. Lowther. It is to be hoped that there will be sufficient public support for the venture to enable it to be continued and to afford the necessary encouragement to $\mathrm{Mr}$. C. C. Fagg, who has been the organizer.

\section{Indian Forest College, Dehra Dun}

The Progress Report of the Indian Forest College, Dehra Dun, 1940-41 (Manager, Government of India Press, New Delhi, 1941), states that the College was opened in May 1938, after a period of closure, for the training of candidates for the Superior Forest Services of the various Provinces and States of India. The course extends over two years, each class completing its course before a fresh class is admitted, so that there are no overlapping classes. This first course lasted from May 1938 until March 1940. The report in question covers the first year's work of the second course, which was to end in March 1942. At the prize-giving at the end of the first two-year course the President and Principal of the College both spoke in laudatory terms of the work achieved and the type of man and training which the College is turning out.

The movement will be watched anxiously by old Indian forest officers, who have seen the growth of, and the fine results attained by, the Indian Forest Service. They ask how will the standard be main tained by a series of devolutionized, entirely independent forest departments in the provinces, staffed in the higher grades in the future by men trained in a college the staff of which has had no opportunities of rubbing shoulders with confreres in their own subjects. Moreover, men trained in this fashion will not have had the advantage of training in one of the old universities, where they mix with men who are getting other courses of education; and finally they will not have the opportunity of combining this training with visits to European continental forests which is so desirable.

\section{The Night Sky in January}

New moon occurs on January 6d. 12h. $37 \mathrm{~m}$. and full moon on January $21 \mathrm{~d}$. $10 \mathrm{~h} .48 \mathrm{~m}$. The following conjunctions take place during the month: Jan. $4 \mathrm{~d}$. 10h., Mars in conjunction with the moon, Mars $5^{\circ}$ S.; Jan. 7d. 22h., Mercury in conjunction with the moon, Mercury $3^{\circ} \mathrm{S}$.; Jan. 16d. 10h., Mercury in conjunction with Venus, Mercury $2 \cdot 7^{\circ} \mathrm{N}$.; Jan. 16d. 19h., Saturn in conjunction with the moon, Saturn $3^{\circ}$ N.; Jan. 20d. 12h., Jupiter in conjunction with the moon, Jupiter $3^{\circ} \mathrm{N}$. Occultations of stars brighter than magnitude 6 are as follows, the times referring to Greenwich :

$\begin{array}{ccc}\text { d. } & \text { h. } & \text { m. } \\ \text { Jan. } 14 & 19 & \mathbf{4 3 \cdot 2} \\ 15 & 17 & 37 \cdot 7 \\ 16 & 17 & 31 \cdot 0 \\ 16 & 23 & 25 \cdot 6 \\ 16 & 23 & 46 \cdot 6 \\ 17 & 00 & 32 \cdot 9 \\ 25 & 00 & 29 \cdot 8\end{array}$

$\begin{array}{rll}\mu & \text { Ceti } & \text { D } \\ f & \text { Tauri } & \text { D } \\ \gamma & \text { Tauri } & \text { D } \\ \boldsymbol{\theta}^{\prime} & \text { Tauri } & \text { D } \\ 75 & \text { Tauri } & \text { D } \\ \text { 264B. } & \text { Tauri } & \text { D } \\ \chi & \text { Leonis } & \text { R }\end{array}$

Mercury attains its greatest elongation, $19^{\circ} \mathrm{E}$., on Jan. 8. Venus sets about an hour after the sun in the middle of the month and is not very favourably placed for observation in Great Britain. Jupiter and Saturn continue to be well placed for observation, the former southing about midnight and the latter at $20 \mathrm{~h} .40 \mathrm{~m}$. in the middle of the month. The earth makes its closest approach to the sun on January 2.

\section{Announcements}

Sir John C. G. Ledingham is to retire on March 31 from the post of director of the Lister Institute of Preventive Medicine, which he has held since 1930. To succeed Sir John Ledingham in the directorship, the Governing Body of the Institute has appointed Dr. A. N. Drury, Huddersfield lecturer in special pathology, University of Cambridge, and member of the scientific staff of the Medical Research Council.

AT the annual general meeting of the British Mycological Society on December 12, Dr. S. P. Wiltshire, director of the Imperial Mycological Institute, Kew, Surrey, was elected president for 1943.

THE Board of Trinity College. Dublin, has invited Prof. J. M. O'Connor, professor of physiology in University College, Dublin, to deliver the John Mallet Purser Lecture in 1943.

ThE Central Council for Health Education is making plans for its 1943 Summer School. The School will probably be held at the Chelsea Polytechnic during August 4-14, and will deal with the teaching of biology and with health education generally. While teachers of biology will find the full ten days of value, educational administrators and youth leaders will find the first three days of the School of special interest to them. Further details may be obtained from the Education Officer, Central Council for Health Education, Tavistock House, Tavistock Square, W.C.1. 